\title{
Reporter cell lines to evaluate the selectivity of chemicals for human and zebrafish estrogen and peroxysome proliferator activated $\gamma$ receptors
}

\section{OPEN ACCESS}

Edited by:

Hubert Vaudry,

University of Rouen, France

Reviewed by:

Berta Levavi-Sivan

The Hebrew University, Israel

Taisen Iguchi,

National Institute for Basic Biology,

Japan

*Correspondence:

Patrick Balaguer,

Institut de Recherche en Cancérologie

de Montpellier, Institut National de la

Santé et de la Recherche Médicale

1194, Institut Reigional du Cancer de

Montpellier, Parc Euromédecine, 208

rue des Apothicaires, 34090

Montpellier, France

patrick.balaguer@inserm.fr

Specialty section

This article was submitted to Neuroendocrine Science,

a section of the journal

Frontiers in Neuroscience

Received: 11 December 2014 Accepted: 26 May 2015

Published: 09 June 2015

Citation:

Grimaldi M, Boulahtouf A, Delfosse V,

Thouennon E, Bourguet $W$ and Balaguer P (2015) Reporter cell lines to evaluate the selectivity of chemicals

for human and zebrafish estrogen and

peroxysome proliferator activated $\gamma$

receptors Front. Neurosci. 9:212.

doi: 10.3389/fnins.2015.00212

\author{
Marina Grimaldi 1,2,3,4, Abdelhay Boulahtouf 1,2,3,4, Vanessa Delfosse 5,6, \\ Erwan Thouennon 1, 2,3,4, William Bourguet ${ }^{5,6}$ and Patrick Balaguer 1, 2,3,4*
}

${ }^{1}$ Institut de Recherche en Cancérologie de Montpellier, Montpellier, France, ${ }^{2}$ Institut National de la Santé et de la Recherche Médicale U1194, Montpellier, France, ${ }^{3}$ Université Montpellier, Montpellier, France, ${ }^{4}$ Institut Reigional du Cancer de Montpellier, Montpellier, France, ${ }^{5}$ Institut National de la Santé et de la Recherche Médicale U1054, Montpellier, France,

${ }^{6}$ Centre National de la Recherche Scientifique UMR5048, Centre de Biochimie Structurale, Université Montpellier, Montpellier, France

Zebrafish is increasingly used as an animal model to study the effects of environmental nuclear receptors (NRs) ligands. As most of these compounds have only been tested on human NRs, it is necessary to measure their effects on zebrafish NRs. Estrogen receptors (ER) $\alpha$ and $\beta$ and peroxysome proliferator activated receptor (PPAR) $\gamma$ are main targets of environmental disrupting compounds (EDCs). In humans there are two distinct nuclear ERs ( $h E R \alpha$ and $h E R \beta$ ), whereas the zebrafish genome encodes three ERs, zfER $\alpha, z f E R \beta 1$, and zfER $\beta 2$. Only one isoform of PPAR $\gamma$ is expressed in both humans and zebrafish. In this review, we described reporter cell lines that we established to study the interaction of EDCs with human and zebrafish ERs and PPAR $\gamma$. Using these cell lines, we observed that zfERs are thermo-sensitive while zfPPAR $\gamma$ is not. We also showed significant differences in the ability of environmental and synthetic ligands to modulate activation of zfERs and zfPPAR $\gamma$ in comparison to hERs and hPPAR $\gamma$. Some environmental estrogens (bisphenol A, mycoestrogens) which are hER panagonists displayed greater potency for zfER $\alpha$ as compared to zfER $\beta$ s. hER $\beta$ selective agonists (8$\beta \mathrm{VE} 2$, DPN, phytoestrogens) also displayed zfER $\alpha$ selectivity. Among hER $\alpha$ selective synthetic agonists, $16 \alpha$-LE2 was the most zfER $\alpha$ selective compound. Almost all zfPPAR $\gamma$ environmental ligands (halogenated bisphenol A derivatives, phthalates, perfluorinated compounds) displayed similar affinity for human and zebrafish PPAR $\gamma$ while pharmaceutical hPPAR $\gamma$ agonists like thiazolidones are not recognized by zfPPAR $\gamma$. Altogether, our studies show that all hERs and hPPAR $\gamma$ ligands do not control in a similar manner the transcriptional activity of zfERs and zfPPAR $\gamma$ and point out that care has to be taken in transposing the results obtained using the zebrafish as a model for human physiopathology.

Keywords: estrogen receptor, peroxysome proliferator activated receptor $\gamma$, environmental disrupting compounds, reporter cell lines, human, zebrafish 


\section{Introduction}

Human nuclear hormone receptors (NHRs) are a family of 48 transcription factors, many of which have been shown to be activated by ligands. NHRs regulate cognate gene networks involved in key physiological functions such as cell growth and differentiation, development, homeostasis, or metabolism (Gronemeyer et al., 2004; Germain et al., 2006). Consequently, inappropriate exposure to environmental pollutants often leads to proliferative, reproductive, and metabolic diseases, including hormonal cancers, infertility, obesity or diabetes. NHRs are modular proteins composed of several domains, most notably an N-terminal domain, which harbors a ligand-independent activation function (AF-1), a central DNA-binding domain (DBD), and a C-terminal ligand-binding domain (LBD) hosting a ligand-dependent transcriptional activation function (AF-2) (Gronemeyer et al., 2004). In the absence of the cognate ligand, some NHRs are located in the nucleus, bind to the DNA response elements of their target genes, and recruit corepressors, while others are located in the cytoplasm in an inactive complex with chaperones.

Ligand binding induces major structural alterations of the receptor LBDs, leading to (1) destabilization of corepressor or chaperone interfaces, (2) exposure of nuclear localization signals to allow nuclear translocation and DNA binding of cytoplasmic receptors, and (3) recruitment of coactivators triggering gene transcription through chromatin remodeling and activation of the general transcription machinery. The crystal structures of many NHR LBDs have been determined, revealing a conserved core of $12 \alpha$-helices (H1-H12) and a short twostranded antiparallel $\beta$-sheet (S1 and S2) arranged into a threelayered sandwich fold. This arrangement generates a mostly hydrophobic cavity in the lower half of the domain, which can accommodate the cognate ligand. In all hormone-bound LBD structures, the ligand-binding pocket (LBP) is sealed by helix H12. This conformation is specifically induced by the binding of hormones or synthetic agonists and is referred to as the "active conformation" because it allows the dissociation of corepressors and favors the recruitment of transcriptional coactivators (Bourguet et al., 2000; Renaud and Moras, 2000; Pike, 2006).

In contrast to agonist binding, interaction with antagonists prevents the correct positioning of helix H12, thus avoiding association with the LxxLL motifs of coactivators. The LBD also contributes to the modulation of the N-terminal AF-1 through interdomain crosstalk so that both AF-1 and AF-2 domains can recruit a range of coregulatory proteins and act individually or in a synergistic manner (Benecke et al., 2000; Bommer et al., 2002; Wilson, 2011).

Among nuclear receptors, ERs and PPAR $\gamma$ are main targets of numerous synthetic substances released into the environment by human activities. These substances can act as endocrine-disrupting chemicals (EDCs) causing reproductive, developmental, metabolic, or neurological diseases as well as hormone-related cancers (Diamanti-Kandarakis et al., 2009). Many EDCs are man-made compounds, for example bisphenols, phthalates, parabens, dioxins, pesticides, alkylphenols, organotins, polychlorinated biphenyls, or perfluoroalkyl compounds. Some natural EDCs can also be found in plants and fungi. Standard methods to study interaction of EDCs with these nuclear receptors use stable cell reporter gene assays based on human ERs and PPAR $\gamma$ activation (Balaguer et al., 1999; Legler et al., 1999; Seimandi et al., 2005; Riu et al., 2011a). To address whether chemicals exert an effect at the organismal level, ER activity assays have been developed for zebrafish. In these animals, GFP reporter constructs are designed to act in certain tissues exclusively (such as liver or brain) (Kurauchi et al., 2005; Brion et al., 2012) or in all tissues of embryos and larvae (Gorelick and Halpern, 2011; Lee et al., 2012). Zebrafish has also been used as an in vivo model to study the effect of environmental compounds on PPAR $\gamma$ (Riu et al., 2014). Zebrafish stores neutral lipid triglycerides in visceral, intramuscular, and subcutaneous adipocyte depots (Tingaud-Sequeira et al., 2012). Studies of the zebrafish embryo, which is optically transparent thus facilitating the labeling and detection of lipid depots using lipid staining (Minchin and Rawls, 2011), have shown that white adipose tissue appearance is correlated with size rather than the age of the fish. By using zebrafish as a PAR $\gamma$ ligand screening model, we have showed that halogenated-BPA analogs are potent inducers of lipid accumulation in vivo through PPAR $\gamma$ signaling (Riu et al., 2014).

In order to evaluate the effects of environmental and pharmaceutical compounds on the transcriptional activity of zfERs and zfPPAR $\gamma$ and to compare the data with their activity on hERs and hPPAR $\gamma$, we established human and zebrafish ERs and $\operatorname{PPAR} \gamma$ reporter cell lines in the same cellular context (Balaguer et al., 1999; Seimandi et al., 2005; Pinto et al., 2014; Riu et al., 2014). In HeLa cells stably expressing an ERE-driven luciferase reporter (HELN cells), we expressed the full-length hER $\alpha, \mathrm{hER} \beta$, zfER $\alpha$, zfER $\beta 1$, and zfER $\beta 2$, respectively. Similarly, in HeLa cells stably expressing a GAL4RE-driven luciferase reporter (HG5LN cells), we expressed a fusion protein consisting of the hPPAR $\gamma$ or zfPPAR $\gamma$ ligand binding domain (LBD) and the DNA binding domain (DBD) of the yeast transcription factor GAL4 (GAL4$\operatorname{PPAR} \gamma)$.

The resulting HELN-ERs and HG5LN PPAR $\gamma$ cell lines were used to evaluate the effects of environmental compounds on gene transactivation by the five ERs and the two PPAR $\gamma$, and to compare these effects with results obtained on hER and PPAR $\gamma$ orthologs. Since zebrafish is used as a model for studying the effects of environmental compounds in vivo, determining the transcriptional profiles of these compounds on the zfERs and zfPPAR $\gamma$ is crucial to support the zebrafish model for ER- and $\operatorname{PPAR} \gamma$-related studies and their extrapolation to the mammalian system.

\section{Estrogen Receptors}

Estrogen signaling is mainly mediated by the two estrogen receptors $\mathrm{ER} \alpha$ (also called NR3A1) and $\mathrm{ER} \beta$ (also called NR3A2) (Jensen and Jordan, 2003; Dahlman-Wright et al., 2006) which play important roles in the growth and maintenance of various tissues such as the mammary gland, uterus, bones, or the cardiovascular system. Like most NRs, ERs bind as dimers 
to DNA response elements in the promoter region of target genes and respond to the naturally occurring sex hormone $17 \beta$ estradiol $\left(\mathrm{E}_{2}\right)$. Both hERs are widely distributed throughout the body, displaying distinct but overlapping expression patterns in a variety of tissues (Couse and Korach, 1999). $\mathrm{hER} \alpha$ is primarily expressed in the uterus, liver, kidney, and heart, whereas hER $\beta$ is preferentially expressed in the ovary, prostate, lung, gastrointestinal tract, bladder, and hematopoietic and central nervous systems (Kuiper et al., 1997). However, hER $\alpha$ and hER $\beta$ are coexpressed in a number of tissues including the mammary gland, thyroid, adrenal, bones, and some regions of the brain. Although hER $\alpha$ and hER $\beta$ share similar mechanisms of action, several differences in the transcriptional abilities of each receptor and distinct phenotypes between gene-null animals have been identified, suggesting that these receptors may regulate distinct cellular pathways (Curtis et al., 1996; Couse and Korach, 1999). Interestingly, when hERs are coexpressed, hER $\beta$ exhibits an inhibitory action on ER $\alpha$-mediated gene expression (Pettersson et al., 2000; Liu et al., 2002), so that $\mathrm{hER} \beta$ has been shown to antagonize several $\mathrm{hER} \alpha$-mediated effects including fat reduction and cell proliferation in breast, uterus, or prostate (Ogawa et al., 1998; Weihua et al., 2000; Lindberg et al., 2003). Furthermore, in addition to controlling the normal development and function of the reproductive system and other tissues, estrogens are key regulators of primary breast and prostatic cancer growth (Jensen and Jordan, 2003). Roughly $40 \%$ of human cancers require steroid hormones for their growth and the first-line therapy for treatment of hormonedependent cancers is based on androgen and estrogen antagonists interacting with $\mathrm{AR}$ or ERs and shutting down the corresponding hormone-responsive pathway. Interestingly, ER $\beta$ has been shown to antagonize ER $\alpha$-mediated effects on cell proliferation in the breast, uterus, ovary, and prostate (Weihua et al., 2000; Lindberg et al., 2003; Ellem and Risbridger, 2009). In this regard, estrogens with selectivity for either ER subtypes may produce different biological outcomes, particularly on cancer cell proliferation. Given the widespread role of ERs in human physiology, it is not surprising that environmental compounds which bind to ERs, thus substituting for the natural hormone and deregulating the fine-tuned action of $\mathrm{E}_{2}$, can lead to ER-related disorders including breast, endometrial, colorectal, or prostate cancers, as well as neurodegenerative, inflammatory, immune, cardiovascular, and metabolic diseases.

Small fish including zebrafish (Danio rerio) are increasingly being used as model species to study in vivo effects of EDCs (Segner, 2009; Vosges et al., 2010; Brion et al., 2012). In zebrafish, three zfER subtypes (zfER $\alpha, z f E R \beta 1$, and $z f E R \beta 2)$ are present (Menuet et al., 2002; Hawkins and Thomas, 2004). Zebrafish $\mathrm{ER} \alpha$ (esr1) is orthologous to the human $\mathrm{ER} \alpha$, while $\mathrm{ER} \beta 1$ (esr2b) and ER $\beta 2$ (esr2a) are orthologs of the human ER $\beta$ (Bardet et al., 2002). The overall amino-acid sequence identity between the zfER subtypes and their corresponding human ER orthologs is approximately 50\% (Menuet et al., 2002). ZfERs are differently expressed and regulated in reproductive tissue like gonads, liver, as well as in brain. In adult liver, E2 induces zfER $\alpha$ expression while it has no effect on zfER $\beta 2$ and represses zfER $\beta 1$ expression (Menuet et al., 2002). Moreover, both zfER $\alpha$ and
zfER $\beta 2$ upregulate zfER $\alpha$ expression after E2 exposure, whereas zfER $\beta 1$ has no effect on this expression (Menuet et al., 2004). These studies suggest that the different forms of zfERs have partially distinct and nonredundant functions. Hence, in the perspective of developing fish in vitro assays, it is essential to take into account all zfER subtypes in the assessment of chemical estrogenicity in zebrafish. Since these three zfERs are thought to mediate different biological effects, there is an increased interest in finding subtype-selective zfER ligands.

\section{Estrogen Receptors Reporter Cell Lines}

To understand and to evaluate impact of xenoestrogens on ER-signaling pathway, it is necessary to develop cell-based transcription assay systems that could reflect different cellular contexts and/or different model species. In vitro assays based on reporter gene driven by ERE have been proven to be useful and relevant screening tools to address the large number of chemicals yet needed to be tested for their estrogenic potential. We and other groups have developed stable reporter gene assays based on human $\mathrm{ER} \alpha$ and $\mathrm{ER} \beta$ activation in different cell contexts and successfully used them to characterize estrogenic potency of chemicals (Balaguer et al., 1999; Legler et al., 1999; Wilson et al., 2004; Sotoca et al., 2008; Docquier et al., 2013). In order to take into account the species of origin of studied receptor in hazard assessment of estrogenic chemicals in fish, we have developed in vitro stable reporter gene assays derived from fish species (Molina-Molina et al., 2008; Cosnefroy et al., 2012; Pinto et al., 2014). Among them, HELN-zfER $\alpha$, -zfER $\beta 1$, and -zfER $\beta 2$ (Pinto et al., 2014) reporter cell lines were established in a similar way than HELN-hER $\alpha$ and -hER $\beta$ cell lines (Pinto et al., 2014). Briefly, HELN-ERs cell lines cells were obtained by transfection of HELN cells (HeLa cells stably transfected with the ERE- $\beta$ GlobinLuc-SVNeo plasmid) (Balaguer et al., 1999) by the corresponding pSG5-puro plasmids (pSG5-hER $\alpha$-puro, -hER $\beta$-puro -zfER $\alpha$ puro, -zfER $\beta 1$-puro, and -zfER $\beta 2$-puro, respectively).

\section{Selectivity of Chemicals for Human and Zebrafish Estrogen Receptors}

Screening of endogenous, environmental and synthetic ligands in the HELN-zfER cell lines showed that known mammalian ER ligands are also able to induce transcriptional activity of zebrafish ER subtypes (Pinto et al., 2014). This screening allowed us to assess differences in the potency of the estrogenic compounds among the three zfER subtypes, and compare their selectivity toward hERs using a similar human cellular context. The HELN-zfERs cells were incubated at $28^{\circ} \mathrm{C}$ after addition of chemicals to the cells because it is a more physiologically relevant temperature for zebrafish, which increased the potency of estradiol approximately 10 -fold compared to incubation at $37^{\circ} \mathrm{C}$. Temperature sensitivity of fish ERs has already been reported using reporter gene assays (Matthews et al., 2002; Cosnefroy et al., 2009) and the reason seems to be thermodependence of estrogen binding (Tan et al., 1999; Matthews et al., 2002; Sumida et al., 2003). 
We have shown that there are clear differences between the selectivity of various (anti)estrogens for zebrafish and human ER isoforms, establishing the fact that a direct translation of (anti)estrogenic effects (activities or potencies) from mammals to zebrafish is not possible. Although none of the tested compounds specifically activated either zebrafish or human ERs, transcriptional activities toward human and zebrafish ERs need to be studied.

Natural (E2) and pharmaceutical (EE2) estrogens display similar affinities for hERs and zfERs. Some environmental estrogens ( $\alpha$-zearalanol, bisphenol-A) with similar affinity for hERs preferentially activated $\mathrm{zfER} \alpha$ rather than zfER $\beta$ s. Other environmental estrogens (nonylphenol mixture, 4-tertoctylphenol) with similar affinity for hERs displayed slightly higher affinity for $\mathrm{zfER} \alpha$ and $\mathrm{zfER} \beta 2$ than for $\mathrm{zfER} \beta 1$. Benzophenone 2 and phytoestrogens (genistein, liquiritigenin) which have higher affinity for hER $\beta$ than for hER $\alpha$ also displayed slightly higher affinity for zfER $\alpha$ and zfER $\beta 2$ than for zfER $\beta 1$. Finally, hER $\beta$ selective synthetic compounds ( $8 \beta$-vE2, DPN) preferentially activated zfER $\alpha$ compared to zfER $\beta$ s. On the contrary and similar to hERs, the synthetic compound $16 \alpha-E 2$, which has 1000-fold more selectivity for $\mathrm{hER} \alpha$ (Escande et al., 2006), also exhibited higher affinity for $\mathrm{zfER} \alpha$ compared to the $\mathrm{zfER} \beta$ subtypes and is the most selective compound for $\mathrm{zfER} \alpha$ nowadays (Figure 1; Table 1).

To gain structural insights into the $\mathrm{zfER} \alpha$ selectivity of $16 \alpha$ LE2 in human and zebrafish ERs, we used the web-based server EDMon (Endocrine Disruptor Monitoring; http://atome2. cbs.cnrs.fr/AT2B/SERVER/EDMon.html) (Delfosse et al., 2012) to model zfERs in complex with this ligand. The structural

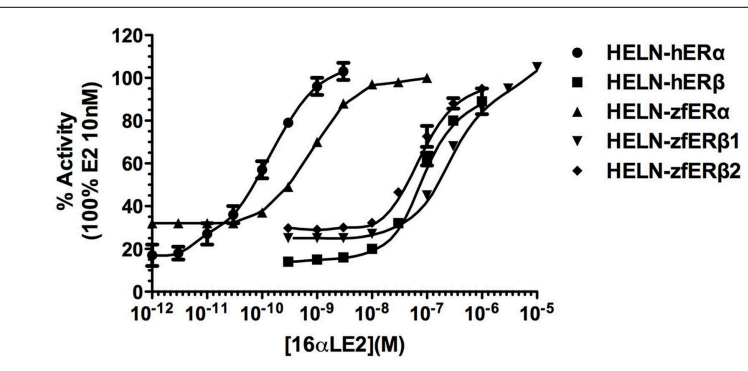

FIGURE 1 | Transcriptional activity of $h E R \alpha, h E R \beta, z f E R \alpha, z f E R \beta 1$, and zfER $\beta 2$ in response to the synthetic pharmaceutical compound 16 $\alpha$-LE2. HELN-hER $\alpha(\bullet)$, -hER $\beta 1$ (ם), -zfER $\alpha(\bigcirc)$, HELN-zfER $\beta 1$ ( $\square$ ), HELN-zfERR2 $(\diamond)$ cells were exposed to different concentrations of $16 \alpha$-LE2. Results are expressed as \% of $10 \mathrm{nM}$ E2 treatment and are derived from Escande et al. (2006) and Pinto et al. (2014).

TABLE 1 | $16 \alpha$ LE2 ERs $\mathrm{EC}_{50}$ and maximal activities.

\begin{tabular}{lcc}
\hline $\mathbf{N R}$ & $\mathbf{E C}_{\mathbf{5 0}}(\mathbf{n M})$ & Maximal activity (\%) \\
\hline $\mathrm{hER} \alpha$ & $0.093 \pm 0.025$ & 100 \\
$\mathrm{hER} \beta$ & $92.9 \pm 1.4$ & 100 \\
zfER $\alpha$ & $0.79 \pm 0.43$ & 100 \\
zfER $\beta 1$ & $240 \pm 30.2$ & 100 \\
zfER $\beta 2$ & $74.6 \pm 7.08$ & 100
\end{tabular}

basis of the $\mathrm{hER} \alpha$ and $\mathrm{hER} \beta$ selectivity toward certain ligands has been associated with two amino acid differences in their ligand-binding pockets. Indeed, L384 and M421 of hER $\alpha$ are replaced by M336 and I373 in hER $\beta$, respectively (Figure 2 and Manas et al., 2004). Superimposition of the 16 $\alpha$-LE2-bound $\mathrm{zfER} \alpha$ model on the crystal structure of $\mathrm{hER} \alpha$ in complex with E2 (PDB code 3UUD) showed that the phenol ring of $16 \alpha$-LE2 occupies the same position as that of E2 and is engaged in a network of hydrogen bonds with E353 from helix 3 (H3) and R394 from H5 (Figure 2A). On the other side of the ligand-binding pocket (LBP), it appears that the hydrogen bond observed between the 17-hydroxyl group of E2 and H524 (H11) is conserved in 16 $\alpha$-LE2. The difference

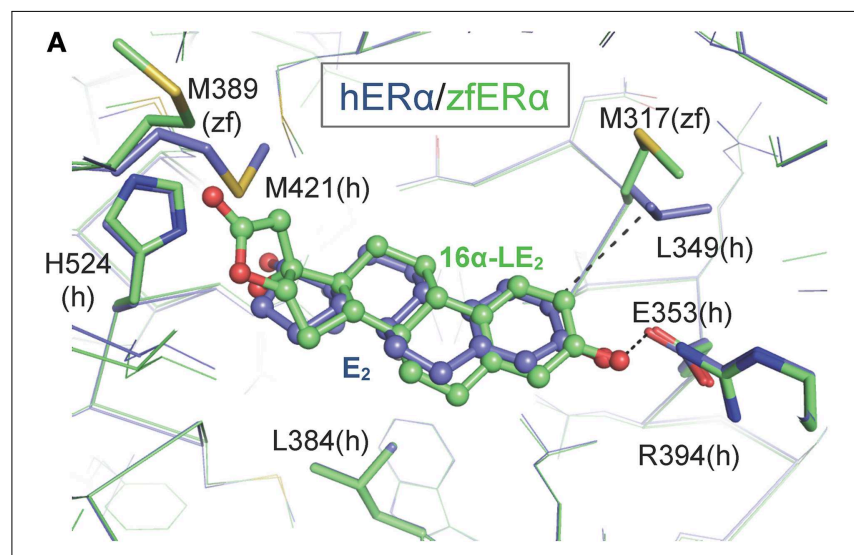

B

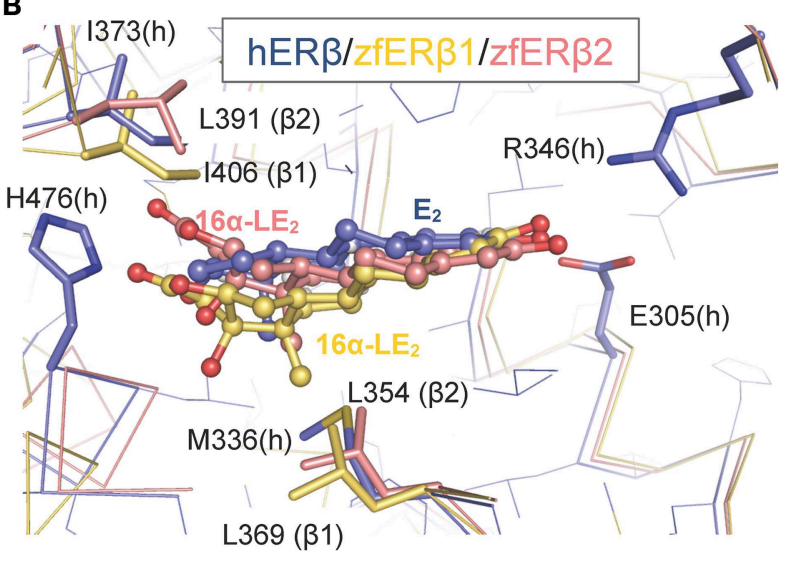

FIGURE 2 | Modeling of the interaction between 16 $\alpha$-LE2 and the human (h) and zebrafish (zf) estrogen receptors. Superposition of the structures of hER $\alpha$ (A) and hER $\beta$ (B) LBDs bound to E2 (blue) on to the molecular models of the 16 $\alpha$-LE2-bound zfER $\alpha$ (A) (green) and

16 $\alpha$-LE2-bound hER $\beta 1$ (red) and 16 $\alpha$-LE2-bound hER $\beta 2$ (yellow) (B) LBDs. In zfER $\alpha$, the lactone ring of $16 \alpha$-LE2 points toward M421 $(\mathrm{H} 7)$ which undergoes a large conformational change (black arrow) to accommodate this additional group. In hER $\beta$, the linear M421 present in $\mathrm{ER} \alpha(\mathrm{M} 389$ in $\mathrm{zfER} \alpha)$ is replaced by branched residues (I373 in hER $\beta$, 1406 in zfER $\beta 1$ and L391 in zfER $\beta 2$ ), which are characterized by a much smaller intrinsic flexibility that maintains the synthetic ligand in a position where it interacts unfavorably with M336 in hER $\beta$, L369 in zfER $\beta 1$ and L354 in zfER $\beta 2$. This figure is derived from Pinto et al. (2014). 
between the two complexes resides in the lactone ring of $16 \alpha-$ LE2 which points toward M421 (H7) that must undergo a large conformational change to accommodate this additional group. In hER $\beta$, the linear M421 is replaced by the branched residue Ileu 373 characterized by a much smaller intrinsic flexibility (Figure 2B). As a consequence, I373 maintains the synthetic ligand in a position where it interacts unfavorably with M336 (H3). Therefore, $16 \alpha$-LE2 adopts different positions in hER $\alpha$ and $\operatorname{hER} \beta$, the more constrained environment provided by the latter accounting for the weaker affinity of the ligand for this receptor subtype. The affinity values measured with the zebrafish receptors reflect the variations in the space constraints provided by the different combinations of residues in the three receptor subtypes. With $\mathrm{H} 3$ and $\mathrm{H} 7$ residues identical to those of the human receptor, $\mathrm{zfER} \alpha$ interacts with $16 \alpha$-LE2 with the highest affinity. The slight difference in the binding affinity of $16 \alpha$-LE2 for $\mathrm{hER} \alpha$ and $\mathrm{zfER} \alpha$ relies most likely on the replacement of L349 (H3) by a methionine residue (M317) (Figure 2A) and a possible loss of a favorable interaction provided by the branched but not by the linear residue (Figure $\mathbf{2 A}$ ). With a conserved isoleucine in H7 (I406) and a leucine residue in H3 (L369) (Figure 2B), zfERß1 displays the most constrained LBP reflecting the weakest binding affinity for $16 \alpha$-LE2. This receptor combines two large residues with low (isoleucine) and medium (leucine) flexibilities. The replacement of $\mathrm{I} 406$ in $\mathrm{H} 7$ of $\mathrm{zfER} \beta 1$ by a leucine residue (L391) (Figure 2B) in zfER $\beta 2$ provides a slight gain in LBP plasticity, in agreement with the slightly better affinity of $16 \alpha$-LE2 for the latter.

The inability of hER $\beta$-selective phytoestrogens (genistein and liquiritigenin) and pharmaceuticals (8bv-E2, DPN) to activate preferentially the $\mathrm{zfER} \beta$ isoforms is explained by the mutation of a critical amino acid involved in genistein binding in hER $\beta$. In all zfERs, the position homologous to hER $\beta$ M336 is occupied, as in $\mathrm{hER} \alpha$, by a leucine residue (Figure 2) (Sassi-Messai et al., 2009). This amino acid change most likely accounts for the lack of obvious selectivity of the phytoestrogens toward the $\mathrm{zfER} \beta$ subtypes.

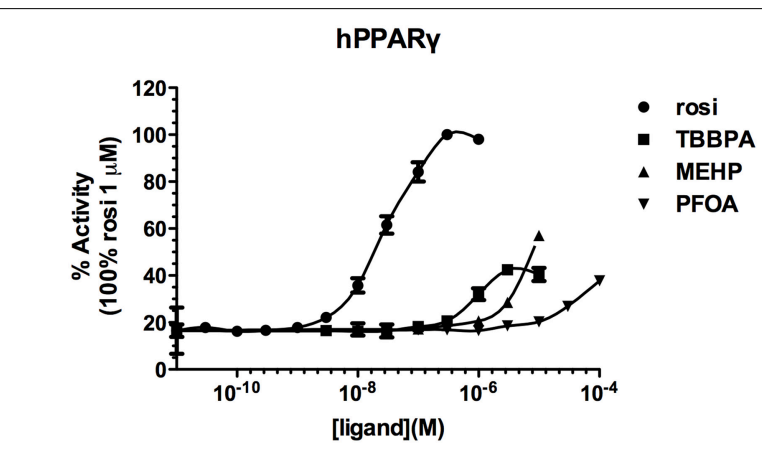

FIGURE 3 | Transcriptional activity of hPPAR $\gamma$ in response to the synthetic pharmaceutical compound rosiglitazone and the environmental compounds TBBPA, MEHP, and PFOA. HG5LN hPPAR and zfPPAR $\gamma$ cells were exposed to different concentrations of rosiglitazone $(\bullet)$, TBBPA ( $\square)$, MEHP $(\bigcirc)$, and PFOA $(\diamond)$. Results are expressed as \% of basal activity and are derived from Riu et al. (2011a).

\section{Peroxysome Proliferator $\gamma$}

PPARs are involved in the regulation of glucose, lipid, and cholesterol metabolism in response to fatty acids and their derivatives, eicosanoids, and drugs used in the treatment of hyperlipidemia and diabetes. The human PPAR subfamily contains three members known as hPPAR $\alpha$, hPPAR $\beta$, and hPPAR $\gamma$. Each hPPAR subtype shows a distinct tissue distribution and ligand preference. hPPAR $\gamma$ is highly expressed in adipose tissue and is a central regulator of lipid storage and adipocyte gene expression and differentiation (Tontonoz et al., 1995) and is involved in various pathophysiological disorders, including metabolic disease, insulin resistance, and diabetes (Rosen and Spiegelman, 2001). hPPAR $\gamma$ is the target for antidiabetic agents of the thiazolidinedione class, which includes troglitazone, pioglitazone, and rosiglitazone. The LBD of hPPAR $\gamma$ is rather large and the diversity of ligands that can be accommodated within its pocket, mainly represented by lipid derivatives, may contribute to the large array of roles that have been assigned to hPPAR $\gamma$. Given the physiological role of hPPAR $\gamma$ in adipose tissue development and maintenance, it has been proposed that disruption of regulation pathways under the control of hPPAR $\gamma$ may be involved in the onset of diabetes and obesity (Swedenborg et al., 2009). Indeed, activation of this receptor by certain xenobiotic compounds has been shown to stimulate adipogenesis in vitro and in vivo through induction

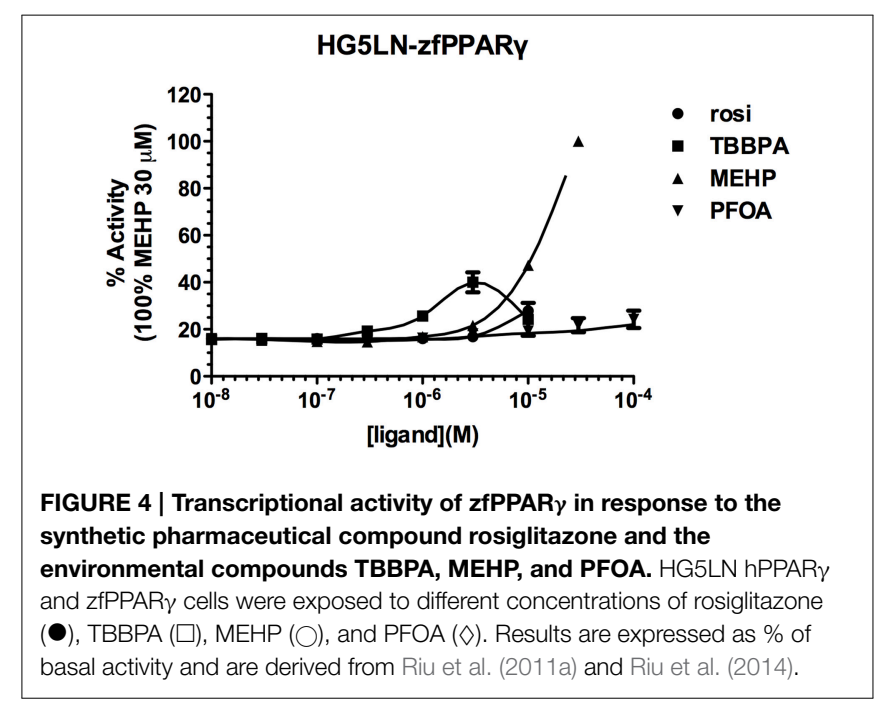

TABLE 2 | EC 50 and maximal activities of PPAR $y$ ligands.

\begin{tabular}{lcc}
\hline & \multicolumn{1}{c}{ hPPAR $\boldsymbol{~}$} & zfPPAR $\boldsymbol{y}$ \\
\cline { 2 - 3 } Ligand & $\begin{array}{c}\mathbf{E C}_{50}(\boldsymbol{\mu} \mathbf{M})(\mathbf{m a x i m a l} \\
\text { activity } \%)\end{array}$ & $\begin{array}{c}\mathbf{E}_{50}(\boldsymbol{\mu} \mathbf{M}) \text { (maximal } \\
\text { activity } \%)\end{array}$ \\
\hline Rosiglitazone & $0.027 \pm 0.003(100)$ & $\mathrm{ND}(27.9)$ \\
TBBPA & $0.762 \pm 0.136(42,4)$ & $1.45 \pm 0.33(40)$ \\
MEHP & $1050 \pm 73(57)$ & $11.3 \pm 1.29(100)$ \\
PFOA & $380 \pm 71(37.8)$ & $\mathrm{ND}(24.2)$ \\
\hline
\end{tabular}

ND, Not determined. 
of the differentiation of preadipocytes of the fibroblastic lineage into mature adipocytes (Grun and Blumberg, 2009; le Maire et al., 2009; Janesick and Blumberg, 2011; Riu et al., 2011a). This has led to the "obesogen hypothesis," according to which, in addition to disruption of the balance between caloric intake and expenditure characterizing modern life-style, the rapidly growing obesity epidemic could also implicate environmental risk factors including an increased exposure to chemicals that interfere with any aspects of metabolism (Grun and Blumberg, 2009; Janesick and Blumberg, 2011, 2012). Accordingly, compounds that have the potential to disrupt any metabolic signaling pathways and lead to increased fat accumulation and obesity are referred to as “obesogens" (Grun and Blumberg, 2006).

Like for ERs, zebrafish begin to be used as model species to study in vivo effects of EDCs on PPAR $\gamma$ (Lyche et al., 2011; Riu et al., 2014). Similar to mammals, zebrafish store neutral lipid triglycerides in the visceral, intramuscular, and subcutaneous adipocyte depots. The first adipocytes, which can be observed from day 8 to 12 , or at a minimal size of about $5 \mathrm{~mm}$ (Imrie and Sadler, 2010), appear in the pancreatic region, then in the viscera, and later on, in the subcutaneous and cranial regions (Flynn et al., 2009; Imrie and Sadler, 2010). Lipid staining can be detected before this stage; however, at this time point, the lipids are not stored in adipocytes, but rather in the yolk, hepatocytes, blood vessels, skeletal myocytes, jaw chondrocytes, and neuronal tissue in the brain (Imrie and Sadler, 2010).

\section{Ppary reporter cell lines}

HG5LN-hPPAR $\gamma$ and $-\mathrm{zPPPAR} \gamma$ reporter cell lines were established in a similar way (Seimandi et al., 2005; Riu et al., 2014). Briefly, HG5LN-PPAR $\gamma$ cell line was obtained by transfection of HG5LN cells (HeLa cells stably transfected with the GALRE5- $\beta$ Globin-Luc-SVNeo plasmid) (Seimandi et al., 2005) by the corresponding pSG5-puro plasmids [pSG5GAL4(DBD)-hPPAR $\gamma(\mathrm{LBD})$-puro and -zfPPAR $\gamma(\mathrm{LBD})$-puro, respectively]. Interestingly, the thermodependence observed for zfERs is not shared by zfPPAR $\gamma$ (Riu et al., 2014).

\section{Selectivity of chemicals for human and zebrafish PPARy}

Screening of environmental and pharmaceutical ligands in the HG5LN-zfPPAR $\gamma$ cell lines showed that known hPPAR $\gamma$ ligands are not always able to induce transcriptional activity of zebrafish

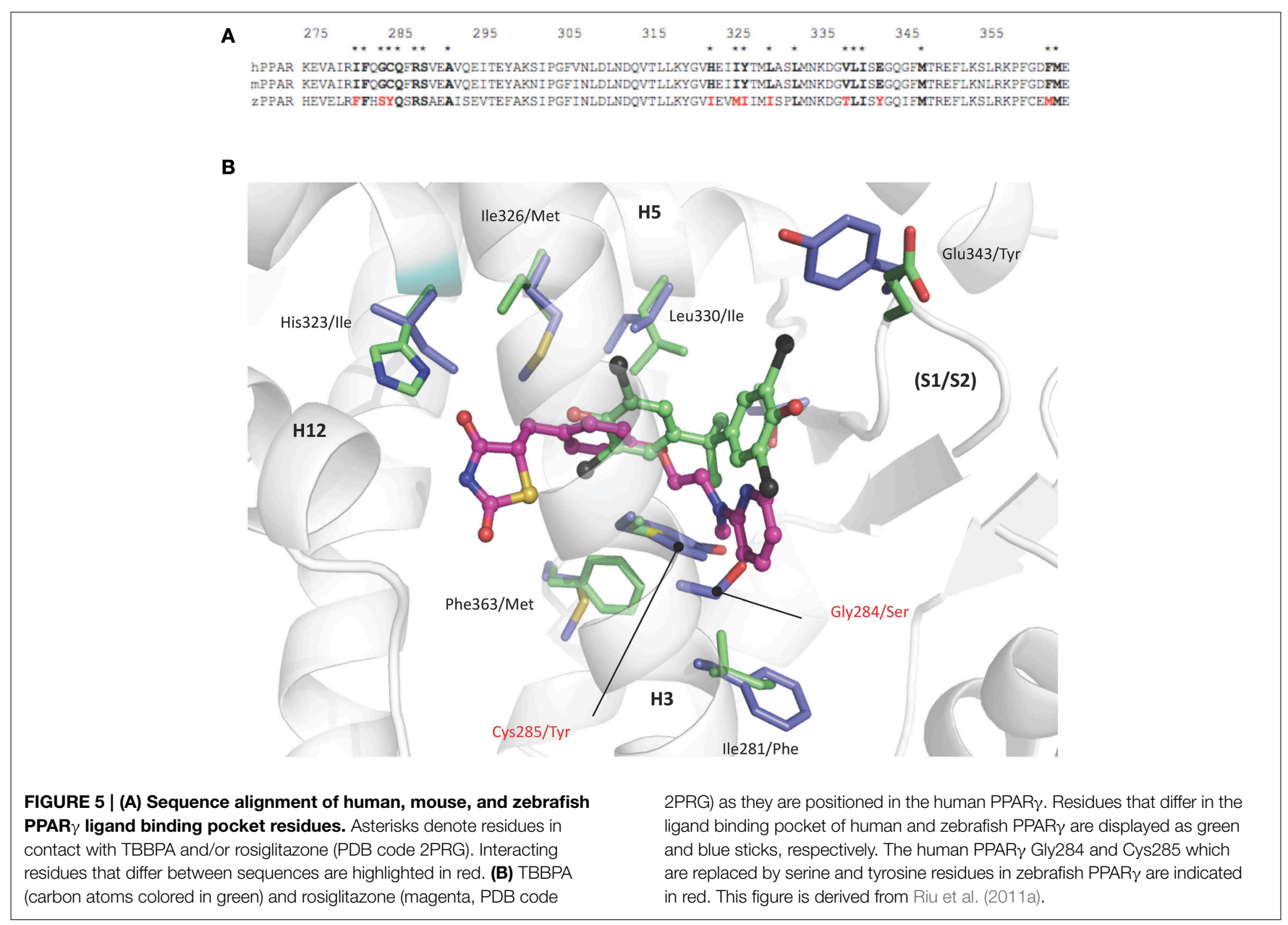


PPAR $\gamma$ (Riu et al., 2011a). Pharmaceutical hPPAR $\gamma$ ligands like thiazolidones (rosiglitazone, troglitazone) do not or very weakly bind to zfPPAR $\gamma$. On the contrary, environmental PPAR $\gamma$ compounds including phthalates (MEHP), perfluorinated compounds (PFOA, PFOS) and halogenated derivatives of BPA (TBBPA, TCBPA) are common activators of hPPAR $\gamma$ and zfPPAR $\gamma$ (Figures 3, 4; Table 2). We also provide evidence that activation of ERs and PPAR $\gamma$ depends on the halogenation degree of BPA analogs. The bulkier are brominated BPA analogs, the greater is their capability to activate PPAR $\gamma$ and the weaker is their estrogenic potential (Riu et al., 2011b).

Comparison of human and zebrafish PPAR $\gamma$ sequences reveals several residue differences which could explain the differential ligand specificity of the various species (Figure 5A). In particular, the replacement of human PPAR $\gamma$ Gly284 and Cys 285 by serine and tyrosine residues in zebrafish $\operatorname{PPAR} \gamma$ provides a rationale for the weak binding affinity of rosiglitazone for this receptor as compared to that observed for the human homolog (Figure 4B). In contrast, the different binding mode of halogenated compounds allows both hPPAR $\gamma$ and zfPPAR $\gamma$ to accommodate TBBPA and TCBPA (Figure 5B).

Structural and biophysical studies revealed that TBT binds to both hRXR and hPPAR $\gamma$ through formation of a covalent bond between the tin atom and the sulfur atom of cysteine residues located in the LBP of both receptors (le Maire et al., 2009; Delfosse et al., 2014). In RXR, this cysteine (Cys432) is located in helix $\mathrm{H} 11$ and is conserved in several species. In contrast, the

\section{References}

Balaguer, P., François, F., Comunale, F., Fenet, H., Boussioux, A. M., Pons, M. et al. (1999). Reporter cell lines to study the estrogenic effects of xenoestrogens. Sci. Total Environ. 233, 47-56. doi: 10.1016/S0048-9697(99)00178-3

Bardet, P. L., Horard, B., Robinson-Rechavi, M., Laudet, V., and Vanacker, J. M. (2002). Characterization of oestrogen receptors in zebrafish (Danio rerio). J. Mol. Endocrinol. 28, 153-163. doi: 10.1677/jme.0.0280153

Benecke, A., Chambon, P., and Gronemeyer, H. (2000). Synergy between estrogen receptor alpha activation functions AF1 and AF2 mediated by transcription intermediary factor TIF2. EMBO Rep. 1, 151-157. doi: 10.1093/emboreports/kvd028

Bommer, M., Benecke, A., Gronemeyer, H., and Rochette-Egly, C. (2002). TIF2 mediates the synergy between RARalpha 1 activation functions AF-1 and AF-2. J. Biol. Chem. 277, 37961-37966. doi: 10.1074/jbc.M206001200

Bourguet, W., Germain, P., and Gronemeyer, H. (2000). Nuclear receptor ligand-binding domains: three-dimensional structures, molecular interactions and pharmacological implications. Trends Pharmacol. Sci. 21, 381-388. doi: 10.1016/S0165-6147(00)01548-0

Brion, F., Le Page, Y., Piccini, B., Cardoso, O., Tong, S. K., Chung, B. C., et al. (2012). Screening estrogenic activities of chemicals or mixtures in vivo using transgenic (cyp19a1b-GFP) zebrafish embryos. PLoS ONE 7:e36069. doi: 10.1371/journal.pone.0036069

Cosnefroy, A., Brion, F, Guillet, B, Laville, N, Porcher, J. M., Balaguer, P., et al. (2009). A stable fish reporter cell line to study estrogen receptor transactivation by environmental (xeno)estrogens. Toxicol. In Vitro 23, 1450-1454. doi: 10.1016/j.tiv.2009.07.003

Cosnefroy, A., Brion, F., Maillot-Maréchal, E., Porcher, J. M., Pakdel, F., Balaguer, P., et al. (2012). Selective activation of zebrafish estrogen receptor subtypes by chemicals by using stable reporter gene assay developed in a zebrafish liver cell line. Toxicol. Sci. 125, 439-449. doi: 10.1093/toxsci/kfr297 cysteine residue of PPAR $\gamma$ (Cys285) resides in $\mathrm{H} 3$ and is not conserved in several species including zebrafish.

\section{Conclusion}

We have shown above that there are clear differences between the activity of various EDCs for zebrafish and human ERs and PPARs, demonstrating that a direct translation of effects from mammals to zebrafish is not possible. The differences revealed in this study, in terms of transcriptional activities toward human and zebrafish ERs and PPARs, highlight the need to take into account the species of origin when assessing the potency of chemicals. This is particularly important with regard to EDCs screening for hazard assessment since at the present time established test guidelines are only based on human cell lines expressing human nuclear receptors.

To this end, such in vitro cell lines expressing zebrafish nuclear receptors can serve as useful screening tools to address nuclear receptor potency of chemicals for fish models. Hence, an initial screening should be followed up with an NR-subtype specific analysis using both human and zebrafish NRs to elucidate the full spectrum of NR-mediated EDCs effects.

\section{Acknowledgments}

We would like to acknowledge the financial support from the Agence Nationale de la Recherche, project PROOFS and TOXSYN.

Couse, J. F., and Korach, K. S. (1999). Estrogen receptor null mice: what have we learned and where will they lead us? Endocr. Rev. 20, 358-417. doi: 10.1210/edrv.20.3.0370

Curtis, S. W., Washburn, T., Sewall, C., DiAugustine, R., Lindzey, J., and Couse, J. F., et al. (1996). Physiological coupling of growth factor and steroid receptor signaling pathways: estrogen receptor knockout mice lack estrogenlike response to epidermal growth factor. Proc. Natl. Acad. Sci. U.S.A. 93, 12626-12630 doi: 10.1073/pnas.93.22.12626

Dahlman-Wright, K., Cavailles, V., Fuqua, S. A., Jordan, V. C., Katzenellenbogen, J. A., Korach, K. S., et al. (2006). International union of pharmacology. LXIV. Estrogen receptors. Pharmacol. Rev. 58, 773-781. doi: 10.1124/pr.58.4.8

Delfosse, V., Grimaldi, M., Cavaillès, V., Balaguer, P., and Bourguet, W. (2014). Structural and functional profiling of environmental ligands for estrogen receptors. Environ. Health Perspect. 122, 1306-1313. doi: 10.1289/ehp.1408453

Delfosse, V., Grimaldi, M., Pons, J. L., Boulahtouf, A., le Maire, A., Cavailles, V., et al. (2012). Structural and mechanistic insights into bisphenols action provide guidelines for risk assessment and discovery of bisphenol A substitutes. Proc. Natl. Acad. Sci. U.S.A. 109, 14930-14935. doi: 10.1073/pnas.1203574109

Diamanti-Kandarakis, E., Bourguignon, J. P., Giudice, L. C., Hauser, R., Prins, G. S., Soto, A. M., et al. (2009). Endocrine-disrupting chemicals: an endocrine society scientific statement. Endocr. Rev. 30, 293-342. doi: 10.1210/er.2009-0002

Docquier, A., Garcia, A., Savatier, J., Boulahtouf, A., Bonnet, S., Bellet, V., et al. (2013). Negative regulation of estrogen signaling by ER $\beta$ and RIP140 in ovarian cancer cells. Mol. Endocrinol. 27, 1429-1441. doi: 10.1210/me.2012-1351

Ellem, S. J., and Risbridger, G. P. (2009). The dual, opposing roles of estrogen in the prostate. Ann. N.Y. Acad. Sci. 1155, 174-186. doi: 10.1111/j.17496632.2009.04360.x

Escande, A., Pillon, A., Servant, N., Cravedi, J. P., Larrea, F., and Muhn, P., et al. (2006). Evaluation of ligand selectivity using reporter cell lines stably expressing estrogen receptor alpha or beta. Biochem. Pharmacol. 71, 1459-1469. doi: 10.1016/j.bcp.2006.02.002 
Flynn, E. J. III., Trent, C. M., and Rawls, J. F. (2009). Ontogeny and nutritional control of adipogenesis in zebrafish (Danio rerio). J. Lipid. Res. 50, 1641-1652. doi: 10.1194/jlr.M800590-JLR200

Germain, P., Staels, B., Dacquet, C., Spedding, M., and Laudet, V. (2006). Overview of nomenclature of nuclear receptors. Pharmacol. Rev. 58, 685-704. doi: 10.1124/pr.58.4.2

Gorelick, D. A. and Halpern, M. E. (2011). Visualization of estrogen receptor transcriptional activation in zebrafish. Endocrinology 152, 2690-2703. doi: 10.1210/en.2010-1257

Gronemeyer, H., Gustafsson, J. A., and Laudet, V. (2004). Principles for modulation of the nuclear receptor superfamily. Nat. Rev. Drug Discov. 3, 950-964. doi: 10.1038/nrd1551

Grun, F., and Blumberg, B. (2006). Environmental obesogens: organotins and endocrine disruption via nuclear receptor signaling. Endocrinology 147, S50-S55 doi: 10.1210/en.2005-1129

Grun, F., and Blumberg, B. (2009). Endocrine disrupters as obesogens. Mol. Cell. Endocrinol. 304, 19-29. doi: 10.1016/j.mce.2009.02.018

Hawkins, M. B., and Thomas, P. (2004). 17alpha-ethinylestradiol disrupts the ontogeny of the forebrain GnRH system and the expression of brain aromatase during early development of zebrafish. Endocrinology 145, 2968-2977. doi: 10.1210/en.2003-0806

Imrie, D., Sadler, K. C. (2010). White adipose tissue development in zebrafish is regulated by both developmental time and fish size. Dev. Dyn. 239, 3013-3023. doi: 10.1002/dvdy.22443

Janesick, A., and Blumberg, B. (2011). Minireview: PPAR $\gamma$ as the target of obesogens. J. Steroid Biochem. Mol. Biol. 127, 4-8. doi: 10.1016/j.jsbmb.2011.01.005

Janesick, A., and Blumberg, B. (2012). stem cells and the developmental programming of obesity. Int. J. Androl. 35, 437-448. doi: 10.1111/j.13652605.2012.01247.x

Jensen, E. V., and Jordan, V. C. (2003). The estrogen receptor: a model for molecular medicine. Clin. Cancer Res. 9, 1980-1989.

Kuiper, G. G., Carlsson, B., Grandien, K., Enmark, E., Häggblad, J., Nilsson, S., et al. (1997). Comparison of the ligand binding specificity and transcript tissue distribution of estrogen receptors alpha and beta. Endocrinology 138, 863-870.

Kurauchi, K., Nakaguchi, Y., Tsutsumi, M., Hori, H., Kurihara, R., Hashimoto, S., et al. (2005). In vivo visual reporter system for detection of estrogen-like substances by transgenic medaka. Environ. Sci. Technol. 39, 2762-2768. doi: $10.1021 /$ es0486465

Lee, O., Tyler, C. R., and Kudoh, T. (2012). Development of a transient expression assay for detecting environmental oestrogens in zebrafish and medaka embryos. BMC Biotechnol. 12:32. doi: 10.1186/1472-6750-12-32

Legler, J., van den Brink, C. E., Brouwer, A., Murk, A. J., van der Saag, P. T., Vethaak, A. D., et al. (1999). Development of a stably transfected estrogen receptor-mediated luciferase reporter gene assay in the human T47D breast cancer cell line. Toxicol. Sci. 48, 55-66. doi: 10.1093/toxsci/48.1.55

le Maire, A., Grimaldi, M., Roecklin, D., Dagnino, S., Vivat-Hannah, V., Balaguer, P., et al. (2009). Activation of RXR-PPAR heterodimers by organotin environmental endocrine disruptors. EMBO Rep. 10, 367-373. doi: 10.1038/embor.2009.8

Lindberg, M. K., Moverare, S., Skrtic, S., Gao, H., Dahlman-Wright, K., Gustafsson, J. A., et al. (2003). Estrogen receptor (ER)-beta reduces ERalpha-regulated gene transcription, supporting a "ying yang" relationship between ERalpha and ERbeta in mice. Mol. Endocrinol. 17, 203-208. doi: 10.1210/me.2002-0206

Liu, M. M., Albanese, C., Anderson, C. M., Hilty, K., Webb, P., Uht, R. M., et al. (2002). Opposing action of estrogen receptors alpha and beta on cyclin D1 gene expression. J. Biol. Chem. 277, 24353-24360. doi: 10.1074/jbc.M201829200

Lyche, J. L., Nourizadeh-Lillabadi, R, Karlsson, C, Stavik, B, Berg, V, Skåre, J. U., et al. (2011). Natural mixtures of POPs affected body weight gain and induced transcription of genes involved in weight regulation and insulin signaling. Aquat. Toxicol. 102, 197-204. doi: 10.1016/j.aquatox.2011.01.017

Manas, E. S., Xu, Z. B., Unwalla, R. J., and Somers, W. S. (2004). Understanding the selectivity of genistein for human estrogen receptor-beta using X-ray crystallography and computational methods. Structure 12, 2197-2207. doi: 10.1016/j.str.2004.09.015

Matthews, J. B., Fertuck, K. C., Celius, T., Huang, Y. W., Fong, C. J., and Zacharewski, T. R. (2002). Ability of structurally diverse natural products and synthetic chemicals to induce gene expression mediated by estrogen receptors from various species. J. Steroid Biochem. Mol. Biol. 82, 181-194. doi: 10.1016/S0960-0760(02)00159-0

Menuet, A., Le Page, Y., Torres, O., Kern, L., Kah, O., and Pakdel, F. (2004). Analysis of the estrogen regulation of the zebrafish estrogen receptor (ER) reveals distinct effects of ERalpha, ERbeta1 and ERbeta2. J. Mol. Endocrinol. 32, 975-986. doi: 10.1677/jme.0.0320975

Menuet, A., Pellegrini, E, Anglade, I, Blaise, O, Laudet, V, Kah, O., et al. (2002). Molecular characterization of three estrogen receptor forms in zebrafish: binding characteristics, transactivation properties, and tissue distributions. Biol. Reprod. 66, 1881-1892. doi: 10.1095/biolreprod66. 6.1881

Minchin, J. E., and Rawls, J. F. (2011). In vivo analysis of white adipose tissue in zebrafish. Methods Cell Biol. 105, 63-86. doi: 10.1016/b978-0-12-3813206.00003-5

Molina-Molina, J. M., Escande, A., Pillon, A., Gomez, E., Pakdel, F., Cavaillès, V., et al. (2008). Profiling of benzophenone derivatives using fish and human estrogen receptor-specific in vitro bioassays. Toxicol. Appl. Pharmacol. 232, 384-395. doi: 10.1016/j.taap.2008.07.017

Ogawa, S., Eng, V., Taylor, J., Lubahn, D. B., Korach, K. S., and Pfaff, D. W. (1998). Roles of estrogen receptor alpha gene expression in reproduction-related behaviors in female mice. Endocrinology 139:5070-5081.

Pettersson, K., Delaunay, F., and Gustafsson, J. A. (2000). Estrogen receptor beta acts as a dominant regulator of estrogen signaling Oncogene 19, 4970-4978 doi: 10.1038/sj.onc. 1203828

Pike, A. C. (2006). Lessons learnt from structural studies of the oestrogen receptor. Best Pract. Res. Clin. Endocrinol. Metab. 20, 1-14. doi: 10.1016/j.beem.2005.09.002

Pinto, C., Grimaldi, M., Boulahtouf, A., Pakdel, F., Brion, F., Aït-Aïssa, S., et al. (2014). Selectivity of natural, synthetic and environmental estrogens for zebrafish estrogen receptors. Toxicol. Appl. Pharmacol. 280, 60-69. doi: 10.1016/j.taap.2014.07.020

Renaud, J. P., and Moras, D. (2000). Structural studies on nuclear receptors. Cell. Mol. Life Sci. 57, 1748-1769. doi: 10.1007/PL00000656

Riu, A., Grimaldi, M., le Maire, A., Bey, G., Phillips, K., Boulahtouf, A., et al. (2011a). Peroxisome proliferator-activated receptor $\gamma$ is a target for halogenated analogs of bisphenol A. Environ. Health Perspect. 119, 1227-1232. doi: 10.1289/ehp.1003328

Riu, A., le Maire, A., Grimaldi, M., Audebert, M., Hillenweck, A., Bourguet, W., et al. (2011b). Characterization of novel ligands of $\operatorname{ER} \alpha, \operatorname{ER} \beta$, and PPAR $\gamma$ : the case of halogenated bisphenol A and their conjugated metabolites. Toxicol. Sci. 122, 372-382. doi: 10.1093/toxsci/kfr 132

Riu, A., McCollum, C. W., Pinto, C. L., Grimaldi, M., Hillenweck, A., Perdu, E., et al. (2014). Halogenated bisphenol-A analogs act as obesogens in zebrafish larvae (Danio rerio). Toxicol. Sci. 139, 48-58. doi: 10.1093/toxsci/ kfu036

Rosen, E. D., and Spiegelman, B. M. (2001). PPAR $\gamma$ : a nuclear regulator of metabolism, differentiation, and cell growth. J. Biol. Chem. 276, 37731-37734. doi: 10.1074/jbc.R100034200

Sassi-Messai, S., Gibert, Y., Bernard, L., Nishio, S., Ferri Lagneau, K. F., Molina, J., et al. (2009). The phytoestrogen genistein affects zebrafish development through two different pathways. PLoS ONE 4:e4935. doi: 10.1371/journal.pone.0004935

Segner, H. (2009). Zebrafish (Danio rerio) as a model organism for investigating endocrine disruption. Comp. Biochem. Physiol. C Toxicol. Pharmacol. 149, 187-195. doi: 10.1016/j.cbpc.2008.10.099

Seimandi, M., Lemaire, G., Pillon, A., Perrin, A., Carlavan, I., Voegel, J. J., et al. (2005). Differential responses of PPAR $\alpha, \operatorname{PPAR} \delta$, and PPAR $\gamma$ reporter cell lines to selective PPAR synthetic ligands. Anal. Biochem. 344, 8-15. doi: 10.1016/j.ab.2005.06.010

Sotoca, A. M., Ratman, D., van der Saag, P., Ström, A., Gustafsson, J. A., Vervoort, J., et al. (2008). Phytoestrogen-mediated inhibition of proliferation of the human T47D breast cancer cells depends on the ERalpha/ERbeta ratio. J. Steroid Biochem. Mol. Biol. 112, 171-178. doi: 10.1016/j.jsbmb.2008. 10.002

Sumida, K., Ooe, N, Saito, K, and Kaneko, H. (2003). Limited species differences in estrogen receptor alpha-medicated reporter gene transactivation by xenoestrogens. J. Steroid. Biochem. Mol. Biol. 84, 33-40. doi: 10.1016/S09600760(03)00003-7 
Swedenborg, E., Ruegg, J., Makela, S., and Pongratz, I. (2009). Endocrine disruptive chemicals: mechanisms of action and involvement in metabolic disorders. J. Mol. Endocrinol. 43, 1-10. doi: 10.1677/JME08-0132

Tan, N. S., Frecer, V., Lam, T. J., and Ding, J. L. (1999). Temperature dependence of estrogen binding: importance of a subzone in the ligand binding domain of a novel piscine estrogen receptor. Biochim. Biophys. Acta 1452, 103-120. doi: 10.1016/S0167-4889(99)00128-7

Tingaud-Sequeira, A., Knoll-Gellida, A., André M., and Babin, P. J. (2012). Vitellogenin expression in white adipose tissue in female teleost fish. Biol. Reprod. 86, 38. doi: 10.1095/biolreprod.111. 093757

Tontonoz, P., Hu, E., and Spiegelman, B. M. (1995). Regulation of adipocyte gene expression and differentiation by peroxisome proliferator activated receptor gamma. Curr. Opin. Genet. Dev. 5, 571-576. doi: 10.1016/0959-437X(95) 80025-5

Vosges, M., Le Page, Y., Chung, B. C., Combarnous, Y., Porcher, J. M., Kah, O., et al. (2010). 17alpha-ethinylestradiol disrupts the ontogeny of the forebrain GnRH system and the expression of brain aromatase during early development of zebrafish. Aquat Toxicol. 99, 479-491. doi: 10.1016/j.aquatox.2010. 06.009
Weihua, Z., Saji, S., Makinen, S., Cheng, G., Jensen, E. V., Warner, M., et al. (2000) Estrogen receptor (ER) beta, a modulator of ERalpha in the uterus. Proc. Natl. Acad. Sci. U.S.A. 97, 5936-5941. doi: 10.1073/pnas.97.11.5936

Wilson, E. M. (2011). Analysis of interdomain interactions of the androgen receptor. Methods Mol. Biol. 776, 113-129. doi: 10.1007/978-1-61779-243-4_8

Wilson, V. S., Bobseine, K., and Gray, L. E. Jr. (2004). Development and characterization of a cell line that stably expresses an estrogen-responsive luciferase reporter for the detection of estrogen receptor agonist and antagonists. Toxicol. Sci. 81, 69-77. doi: 10.1093/toxsci/kfh180

Conflict of Interest Statement: The authors declare that the research was conducted in the absence of any commercial or financial relationships that could be construed as a potential conflict of interest.

Copyright (c) 2015 Grimaldi, Boulahtouf, Delfosse, Thouennon, Bourguet and Balaguer. This is an open-access article distributed under the terms of the Creative Commons Attribution License (CC BY). The use, distribution or reproduction in other forums is permitted, provided the original author(s) or licensor are credited and that the original publication in this journal is cited, in accordance with accepted academic practice. No use, distribution or reproduction is permitted which does not comply with these terms. 